\title{
Isolation and molecular detection of Fowl pox and Pigeon pox viruses for the development of live attenuated vaccine seeds from the local isolates
}

\author{
Rebeka Sultana, KHM Nazmul Hossain Nazir, Md. Tanvir Rahman, Shamim Ara Nipa, Md. Mizanur \\ Rahman, Sabiha Sultana Soma, and ${ }^{\bowtie}$ Md. Bahanur Rahman
}

Department of Microbiology \& Hygiene, Bangladesh Agricultural University, Mymensingh-2202, Bangladesh

\begin{tabular}{|c|c|}
\hline ARTICLE INFO ' & Abstract \\
\hline $\begin{array}{l}\text { Article history: } \\
\text { Received : } 29 \text { January } 2019 \\
\text { Accepted : } 22 \text { May } 2019 \\
\text { Published: } 30 \text { June } 2019 \\
\end{array}$ & \multirow{3}{*}{$\begin{array}{l}\text { Avipox is a viral disease of fowl and pigeon which is characterized by proliferative and nodular lesions in } \\
\text { the feather-free parts of the skin or fibro-necrotic and proliferating part in the mouth, esophagus, and } \\
\text { mucous membrane of the upper respiratory tract. This investigation was carried out with an aim to isolate } \\
\text { and molecular detection of Fowl pox virus (FPV) and Pigeon pox virus (PPV) for development of live } \\
\text { attenuated vaccine seeds from the local virus isolates. In this study, nodular lesions were collected from } \\
\text { seven pigeons and four chickens from different areas of Mymensingh in Bangladesh which were affected } \\
\text { by pox. Viral inoculums were prepared and DNA materials were extracted for PCR-based identification of } \\
P 4 b \text { genes. Detection of virus was confirmed by PCR following propagation into 9-11 days old } \\
\text { embryonated chicken egg (ECE) and also chicken embryo fibroblast (CEF) cell culture All the field } \\
\text { samples were found positive for FPV and PPV by PCRR. These field isolates were propagated and } \\
\text { attenuated in duck embryo through CAM route and duck embryo fibroblast (DEF) cell culture for the } \\
\text { development of live attenuated vaccine seeds. Attenuation of both FPV and PPV were successful in duck } \\
\text { embryo through CAM route and duck embryo fibroblast (DEF) cell culture after serial six passages. } \\
\text { Attenuation of the virus was confirmed by inoculation into experimental birds. Inoculation of attenuated } \\
\text { FPV and PPV in chicken and pigeon respectively exhibited no pox lesions whereas control chicken and } \\
\text { pigeon inoculated with field isolates develop nodular lesions. Both FPV and PPV were confirmed from } \\
\text { both groups of birds by PCR. These attenuated local isolates of FPV and PPV could be used as potential } \\
\text { vaccine candidates for the prevention and control of fowl pox and pigeon pox in Bangladesh. }\end{array}$} \\
\hline $\begin{array}{l}\text { Keywords: } \\
\text { Fowl pox virus, Pigeon pox virus, } \\
\text { PCR, CEF, DEF, Propagation, } \\
\text { Attenuation }\end{array}$ & \\
\hline $\begin{array}{l}\text { Correspondence: } \\
\text { Md. Bahanur Rahman } \\
\text { 凶: bahanurr@bau.edu.bd }\end{array}$ & \\
\hline
\end{tabular}

\section{Copyright:}

(c) (7)

(-2019 by authors and BAURES. This work is licensed under the Creative Commons Attribution International License (CC By 4.0).

\section{Introduction}

Pox is a contagious disease of domestic and wild birds of all ages, sexes and breeds which is caused by pox virus belong the genus Avipoxvirus of family Poxviridae and subfamily Chordopoxvirinae. There are 25 different members of the genus Avipoxvirus (Weli and Tryland, 2011). It is a common viral disease of commercial poultry as well as of domestic and wild birds. There are three main strains of the virus, these are Fowl pox, Pigeon pox and Canary pox (Elias et al.,2014).The genus avipox virus includes Fowl pox virus (FPV), Pigeon pox virus (PPV), Turkey pox virus (TPV), Canary pox virus (CPV) and Mynah pox virus (MPV). The viruses are antigenetically and immunologically distinguishable from each other but there is a cross relationship for this strain identification is complicated (Elias et al., 2014).

The disease is associated with proliferative and nodular lesions in the featherless parts of the skin or fibronecrotic and proliferating lesions in the mouth, esophagus, and mucous membrane of the upper respiratory tract (Tripathy and Cunningham, 1984). The disease has two types- 1) Dry or cutaneous pox and 2)
Wet or diptheria pox. Wet pox is the more severe form of the disease, with higher mortality rate in affected birds. Wet pox alone can cause high mortality of up to $50-60 \%$ in unvaccinated birds. In layers, the disease causes a drop in egg production and reduces growth and development in young chicks and pullets (Hy-Line International 2016). The incubation period of the virus varies from about 4-10 days in chickens. Clinical signs of the disease may vary according to host susceptibility, virulence of the virus strain, and distribution of lesion (Tripathy and Reed, 2003). The virus can enter through tiny breaks in the skin or mouth lining, possibly through shared feed and water, or transmitted by mosquitoe bites. The sources of infections are contaminated environment, carrier birds and mosquitoes. The survivability of the virus is for long time in the environment. There are several factors which plays an important role for increase in the incidence of the disease. Those factors are: breed differences, management practices and environmental conditions (Elias et al., 2014).

Vaccination is an actual measure for prevention and control of avipoxvirus. The two attenuated live vaccines 
namely FPV and PPV are commonly used for immunization of birds to protect Fowl pox and Pigeon pox in chicken and pigeon. For attenuated live Fowl pox and Pigeon pox vaccine seeds development, five to six passages of the filed isolates of Fowl pox virus and Pigeon pox virus performed in duck embryo or duck embryo fibroblast cell culture system. However, a larger number of passages can be used, if desired (Geleczei et al., 1969).Vaccination at proper age and dose with dependable vaccines are the most effective means of controlling Fowl pox and Pigeon pox.

Few research work has been carried out for isolation, molecular detection and vaccine development of FPV and PPV in Bangladesh(Islam et al., 2008; Siddique et al., 2011;Kabir et al., 2015; Rahman et al., 2019). But these studies did not focused on developing live attenuated FPV and PPV vaccine in embryonated egg and fibroblast cell culture. Considering these facts, the aim of this study was to isolate and identify Fowl pox and Pigeon pox viruses by molecular techniques from chickens and pigeons and development of live attenuated vaccine seeds.

\section{Materials and Methods Sample Collection}

A total of 11 samples (Fowl Pox=4 and Pigeon Pox=7) were collected from Mymensingh district during the period of January, 2017 to November, 2018. Nodular lesions were screened using sterile blade from Fowl pox (FP) and Pigeon pox infected sick birds and placed in eppendorf tube containing $0.5 \mathrm{ml}$ sterile Virus transport medium (VTM). Samples were immediately transported in the laboratory of Department of Microbiology and Hygiene in cool box containing ice packs. The experimental protocols involving the use of birds and cell cultures were approved by the institutional ethical committee (AWEEC/BAU/2019(5).

\section{Inoculum Preparation}

Both FP and PP suspected birds samples (nodules) were subjected to grinding and mixed with phosphate buffered saline (PBS) for the preparation of $10 \%(\mathrm{w} / \mathrm{v})$ viral suspension. The viral suspensions were then treated by broad spectrum antibiotic gentamycin (Gentin ${ }^{\circledR} 20$, Opsonin Pharma. Ltd., Bangladesh) at $300 \mu 1 / \mathrm{ml}$ for 60 minutes followed by spreading on blood agar supplemented with $5 \%$ bovine blood (HI media, India) and nutrient agar (HI media, India), incubate for 24 hours.

Molecular detection of Fowl pox virus (FPV) and Pigeon pox virus (PPV)

DNA was extracted by chemical method using SV total RNA isolation system (Promega, USA) according to the protocol described by the manufacturer. $P 4 b$ gene specific PCR was performed in a thermal cycler (Mastercycler, Eppendorf, Germany) using the condition described by Roy et al. (2013) with slide modification. The $P 4 b$ gene primer sequence has given in Table 1 . A $25 \mu 1$ of PCR mixture was prepared by mixing green
PCR master mix (Promega ${ }^{\circledR}$, USA) $(12.5 \mu \mathrm{l})$, forward primer $(1 \mu l)$, reverse primer $(1 \mu \mathrm{l})$, nuclease free water $(3.5 \mu \mathrm{l})$ and template DNA $(7 \mu \mathrm{l})$. Thermal profile used for the amplification of $P 4 b$ gene was: initial denaturation at $94^{\circ} \mathrm{C}$ for $5 \mathrm{~min}$; followed by 35 cycles of reaction consisting of $94^{\circ} \mathrm{C}$ for 45 seconds, $48^{\circ} \mathrm{C}$ for 1.5 $\min , 60^{\circ} \mathrm{C}$ for $2 \mathrm{~min}$, along with final extension at $60^{\circ} \mathrm{C}$ for $10 \mathrm{~min}$. The PCR products were analyzed using $1.5 \%$ agarose gel (Sigma-Aldrich, USA).

Table 1. Primers used for $P 4 b$ gene of FPV and PPV detection

\begin{tabular}{llcc}
\hline Primer & \multicolumn{1}{c}{ Sequence (5'-3') } & $\begin{array}{c}\text { Amplicon } \\
\text { size }\end{array}$ & References \\
\hline p2fPF & CAGCAGGTGCTAAAC & $\mathbf{5 7 8 ~ b p}$ & \multicolumn{1}{c}{ Lee and } \\
& AACAA & & Lee (1997) \\
\hline p2fPR & $\begin{array}{l}\text { CGGTAGCTTAACGCC } \\
\text { GAATA }\end{array}$ & & \\
\hline
\end{tabular}

Isolation, Propagation and PCR detection of FPV and PPV

The inoculums were inoculated into 9-11 days-old embryonated chicken eggs (ECE) at the doses of $0.2 \mathrm{ml}$ through chorioallantoic membrane (CAM) route and 1 $\mathrm{ml}$ in chicken embryo fibroblast (CEF) cell culture for primary propagation and isolation of viruses. Simultaneously DNA was extracted directly using kit (SV Total RNA isolation system, Promega, USA) from the inoculum for performing PCR targeting $P 4 b$ gene to detect the positive samples.

\section{Attenuation of Fowl pox virus (FPV) and Pigeon pox virus (PPV)}

After primary propagation, and isolation of the viruses in ECE and CEF cell culture and confirmation by PCR, these propagated viruses were further inoculated into embryonated duck egg (EDE) at the dose of $0.2 \mathrm{ml}$ through CAM route and also $1 \mathrm{ml}$ in duck embryo fibroblast (DEF) cell culture for adaptation and subsequent attenuation. Adaptation of viruses in DEF cell culture was confirmed by observing characteristics cytopathic effect (CPE) using inverted microscope (Carl Zeiss, Germany) and finally confirmed by $P 4 b$ gene specific PCR. After adaptation of viruses both in EDE and DEF cell culture system, the viruses were serially passaged for six times in the systems for live attenuated vaccine seeds preparation.

Determination of TCID $_{50}$ of Fowl pox virus (FPV) and Pigeon pox virus (PPV)

From original virus sample, $100 \mu \mathrm{l}$ virus samples were taken and a series of dilutions at 1:10 of the virus was made. Diluted virus inoculums of $100 \mu \mathrm{l}$ from each dilution were added to each column of the quadruplicate wells. The plates of virus were tapped tightly and tilting was done carefully for 90 minutes. Then $500 \mu$ l of infection media was added to each well. The plate was then kept at $37^{\circ} \mathrm{C}$ for 48 hours and then monitoring of $\mathrm{CPE}$ using the inverted microscope. The number of positive and negative wells was recorded. Result of the 
TCID $_{50}$ titer was calculated by the Reed and Muench (1938) method.

\section{Testing of attenuation in experimental birds}

Attenuation of both Fowl pox and Pigeon pox viruses were checked by inoculating them in experimental birds. For this purpose six chicks and six squabs were bought from local market of Mymensingh. Those birds were divided into two groups $\mathrm{A}$ and $\mathrm{B}$. In case of chicks, two birds in group A and four birds in group B and similarly, in case of squabs, two squabs in group $\mathrm{A}$ and four squabs in group B. Attenuation was confirmed by inoculating the attenuated inoculum of FPV and PPV into group B of both chicks and squabs separately through nasal route at the dose of $0.5 \mathrm{ml}$ (TCID $_{50} 10^{6.67} / \mathrm{ml}$ ) and was observed for two weeks. Group A of both chicks and squabs kept as control and was inoculated by ECE propagated FP and PP virus inoculum through nasal route at the dose of $0.5 \mathrm{ml}$ (TCID $_{50} 10^{6.67} / \mathrm{ml}$ ) and was also observed for two weeks.

\section{Results and Discussion}

Molecular detection of the viruses from field samples In this study, total four Fowl pox suspected field samples (nodular lesions) were randomly collected and used for virus isolation and molecular detection and DNA was extracted from both Fowl pox and Pigeon pox suspected field samples then PCR was performed to detect specific $P 4 b$ gene specific primer. Four out of four Fowl pox virus suspected samples tested was found PCR positive (100\%) and seven out of seven Pigeon pox virus suspected samples tested was found PCR positive (100\%) (Fig. 1; Table 2). Findings of the present study differs with the findings of Masola et al.,(2014), in their study out of 154 investigated samples 66 (42.86\%) were found positive for FPV by PCR. This difference might occur due to large difference of sample number between these studies. In our study only four samples were analyzed, while Masola et al.,(2014) analyzed 154 samples. On the other hand, the molecular detection rate of FPV by Roy et al., (2013) was almost $100 \%$ by PCR and the results of the molecular findings of the present study almost similar with their findings.

Table 2. Detection of Fowl pox virus and Pigeon pox virus in field sample

\begin{tabular}{ccccc}
\hline $\begin{array}{c}\text { Sl. } \\
\text { No }\end{array}$ & Target virus & $\begin{array}{c}\text { Types of } \\
\text { samples }\end{array}$ & $\begin{array}{c}\text { Total no. } \\
\text { of } \\
\text { samples }\end{array}$ & $\begin{array}{c}\text { PCR } \\
\text { positive } \\
\text { samples (\%) }\end{array}$ \\
\hline $\mathbf{1}$ & $\begin{array}{c}\text { Fowl Pox Virus } \\
(\text { FPV) }\end{array}$ & $\begin{array}{c}\text { Nodules from } \\
\text { infected } \\
\text { chickens }\end{array}$ & 04 & $04(100 \%)$ \\
\hline $\mathbf{2}$ & Pigeon Pox & $\begin{array}{c}\text { Nodules from } \\
\text { infected pigeon }\end{array}$ & 07 & $07(100 \%)$ \\
& Virus (PPV) & & & \\
& & & & \\
\end{tabular}

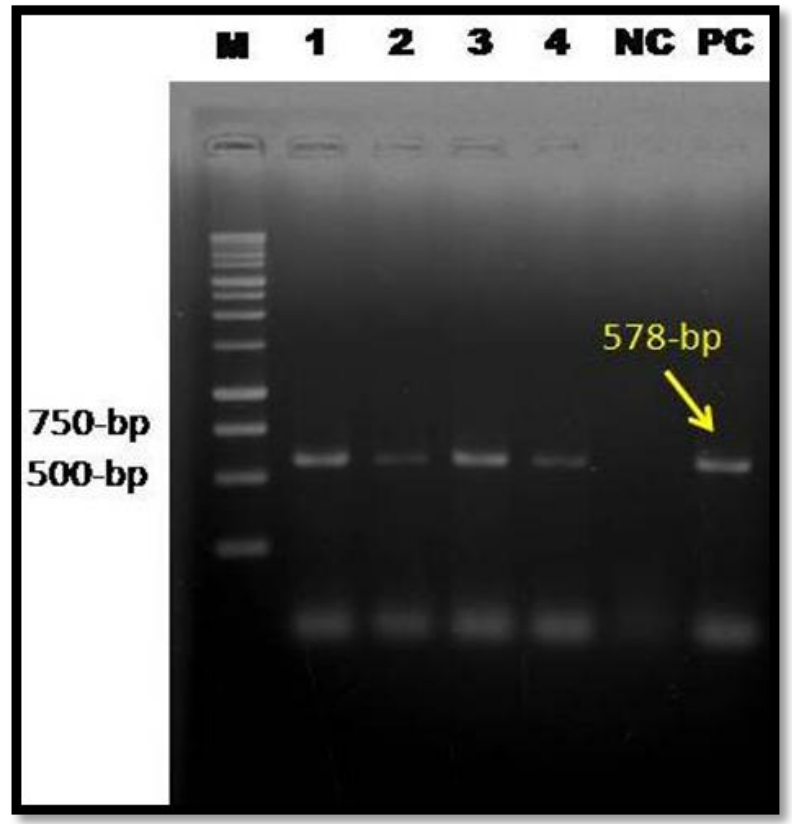

Fig. 1. Electrophoresis results of PCR products of Fowl Pox Virus (FPV) showing specific bands for $P 4 b$ gene on $1.5 \%$ agarose gel. $\mathrm{M}=1 \mathrm{~kb}$ DNA marker; $\mathrm{L} 1$ to $\mathrm{L} 4=$ FPV. NC $=$ Negative control and $\mathrm{PC}=$ Positive control

A total of seven Pigeon pox suspected field samples (nodular lesions) were collected and used for virus isolation and molecular detection. All these seven samples were found positive for avipox virus by PCR (Fig. 2). Finding of the present study was slightly differs from the study of Kabir et al. (2015), who found 32 $(80 \%)$ positive for pigeon pox virus out of 40 samples analyzed.

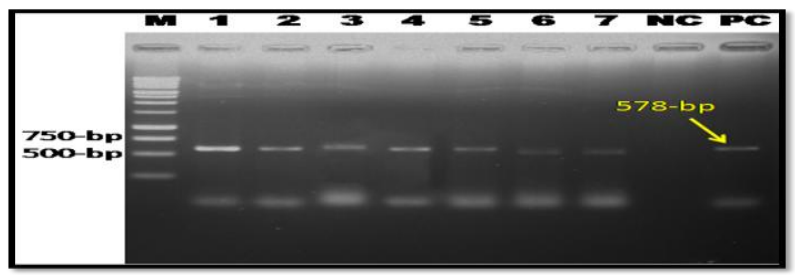

Fig 2. Electrophoresis results of PCR products of Pigeon Pox Virus (PPV) showing specific bands for $P 4 b$ gene on $1.5 \%$ agarose gel. $\mathrm{M}=1 \mathrm{~kb}$ DNA marker; $\mathrm{L} 1$ to $\mathrm{L} 7=$ PPV. $\mathrm{NC}=$ Negative control and $\mathrm{PC}=$ Positive control.

Propagation and PCR detection of FPV and PPV in embryonated chicken eggs (ECE)

For virus isolation and propagation, from each PCR positive field isolates of FPV and PPV two isolates were inoculated in embryonated chicken eggs (ECE) through CAM route and observed. The infected CAM was thickened and haemorrhagic ring observation (Fig. $3 \&$ Fig. 4). Three passages were continued for propagation of FPV and PPV in ECE. 
The finding of present study supports the findings of Kabir et al. (2015), Audarya et al. (2018), Masola et al.(2014) and Roy et al .(2013), who mentioned thickening of CAM upon inoculation with FPV and PPV. Kabir et al.(2015)and other researchers who worked on FPV and PPV reported pock lesions on CAM of chicken embryo inoculated with Fowl pox virus and Pigeon pox virus. But in the present study pock lesion was absent on CAM which is similar with the results of Audarya et al. (2018), who also reported thickening of the CAM.

Propagation and PCR detection of FPV and PPV in Chicken Embryo Fibroblast (CEF) cell culture

Propagation of FPV and PPV in chicken embryo fibroblast (CEF) cell culture was manifested by characteristics cytopathic effect. After inoculation of two PCR positive field isolates of FPV and PPV in CEF separately, the CPE was clear with duration of infection and number of passages. The CPE of FPV and PPV in CEF was observed as round, necrotic, clumping and degeneration of cells and giant cell formation (Fig. $5 \&$ Fig. 6).

Baxendale (1971) reported that all virus strains of avian pox grew satisfactorily on duck and chick embryo cell cultures, but it was found necessary to passage the agents at least three times to obtain a marked CPE. For the accurate and modern technology chicken embryo fibroblast cell culture is useful in order to propagate the field isolate of FPV and PPV to have more concentration and volume of FPV and PPV instead of old and traditional technique of FPV and PPV propagation (Khan, 2014; Balachandran et al., 2012; Yadav et al., 2007). In present study, cytopathic effect (round, necrotic, clumping and degeneration of cells and giant cell formation) was observed for FPV and PPV in case of CEF, 4 to 5 days of post inoculation which is partially similar to the study of Gelenczei et al.(1969), in their study they found that cytopathic effect of FPV and PPV was observed in case of CEF, 3 to 4 days of post inoculation.

Serial passage for attenuation of the FPV and PPV in duck embryo CAM route and PCR detection of attenuated viruses

Two FPV and PPV isolates propagated in chicken embryo and PCR positive samples were used for attenuation. Each PCR positive samples of FPV and PPV were inoculated in duck embryo through CAM route separately at the dose of $0.2 \mathrm{ml}$ and was observed for 7-8 days. After that, the CAMs were collected which were thickened and haemorrhagic (Fig. 7 \& Fig. 8). Then inoculums were prepared from infected CAMs and the inoculums were inoculated into duck embryo and six serial passages were given. Each passage was showed specific $P 4 b$ PCR positive result for both the viruses.

Since several passages in unnatural host help to attenuate the virus, for attenuation of FPV and PPV six passages were given in duck embryo for attenuation. Here the infected CAM were thickened and hemorrhagic which supports the findings of Kabir et al. (2015), Audarya et al. (2018) and Masola et al. (2014) that they also reported thickening of CAM.

Serial passage for attenuation of the FPV and PPV in DEF and PCR detection of attenuated viruses The growth of FPV and PPV in DEF was manifested by characteristics cytopathic effect. After inoculation of chicken embryo fibroblast propagated FPV and PPV infection, the CPE was clear with duration of infection and number of passages. The CPE of FPV and PPV in DEF was observed as round, necrotic, clumping and degeneration of cells and giant cell formation (Fig. 9 \& Fig. 10). Six passages were performed for attenuation of the virus.

In present study, cytopathic effect (round, necrotic, clumping and degeneration of cells and giant cell formation) was observed for FPV and PPV in DEF 6 to 8 days of post inoculation which is partially similar to the study of Geienczei et al. (1969), in their study they found that cytopathic effect of FPV and PPV was observed in DEF, 6 days of post inoculation. In the cell culture system the cell cultured fluid was collected and the virus suspension was used for next passage and six passages were given in DEF for attenuation for the development of live attenuated vaccines according to the study of Geienczei et al. (1969).

\section{Results of determination of TCID $_{50}$ of Fowl pox virus (FPV) and Pigeon pox virus (PPV)}

TCID $_{50}$ of Fowl pox virus (FPV) and Pigeon pox virus (PPV) was calculated by using the formula of Reed and Muench (1938) and TCID ${ }_{50} \log _{10} 6.67 / \mathrm{ml}$ was found for both FPV and PPV.

\section{Checking of attenuation of Fowl pox virus and Pigeon pox virus:}

Attenuation was checked in experimental birds. For this purpose six chicks and six squabs were bought from local market of Mymensingh. Those birds were divided into two groups A and B. In case of chicks, two birds in group A and four birds in group B and similarly, in case of squabs, two squabs in group A and four squabs in group B. Attenuation was confirmed by inoculating the attenuated inoculum of FPV and PPV into group B of both chicks and squabs separately through nasal route at the dose of $0.5 \mathrm{ml}\left(\mathrm{TCID}_{50} 10^{6.67} / \mathrm{ml}\right)$ and within two weeks absence of pox lesions was observed. Group A of both chicks and squabs kept as control and was inoculated by FP and PP virus inoculum through nasal route at the dose of $0.5 \mathrm{ml}\left(\mathrm{TCID}_{50} 10^{6.67} / \mathrm{ml}\right)$. But the pox lesions were observed in the control birds within two weeks.

In this study, attenuation of FPV and PPV was done through six serial passages in duck embryo on CAM and DEF. Previously Gelenczei et al. (1969) also used the 
same procedure for the attenuation of FPV and PPV, since these are not the natural host for the FPV and PPV because several passages in unnatural host help to attenuate the virus. However, in this study instead of using the wing web method the attenuated vaccine seeds were injected into the experimental birds through nasal route at the dose of $0.5 \mathrm{ml}\left(\mathrm{TCID}_{50} 10^{6.67}\right)$. Because Kabir et al. (2015) used three routes (oral, nasal and wing web) of inoculation of FPV and PPV and also the amount of virus $0.5 \mathrm{ml}$ (20\% suspension).

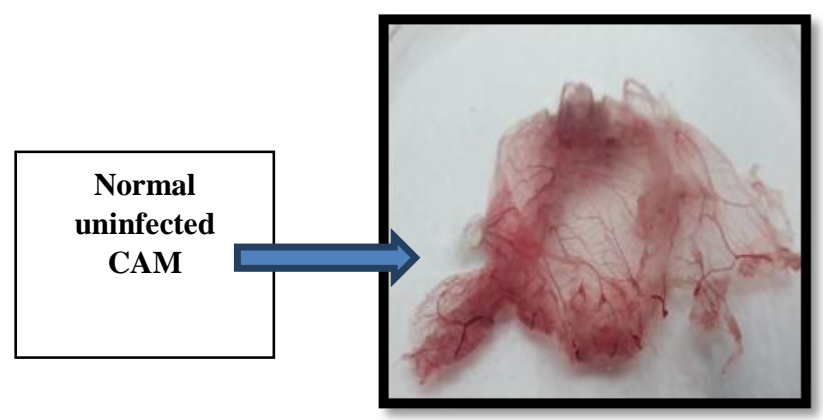

a)
The results of attenuation of FPV and PPV in experimental chicks and squabs (Table 3). No pock lesions were developed in chicks and squabs (Fig. 11 \& Fig. 12) inoculated with attenuated FPV and PPV where as birds infected with chicken embryo propagated virus isolates exhibited pock lesion (Fig. 13 \& Fig. 14). The results of attenuation has showed on Table 3.

Fig. 3. a) Normal uninfected CAM; b) Fowl Pox infected thickened and haemorrhagic Chicken CAM

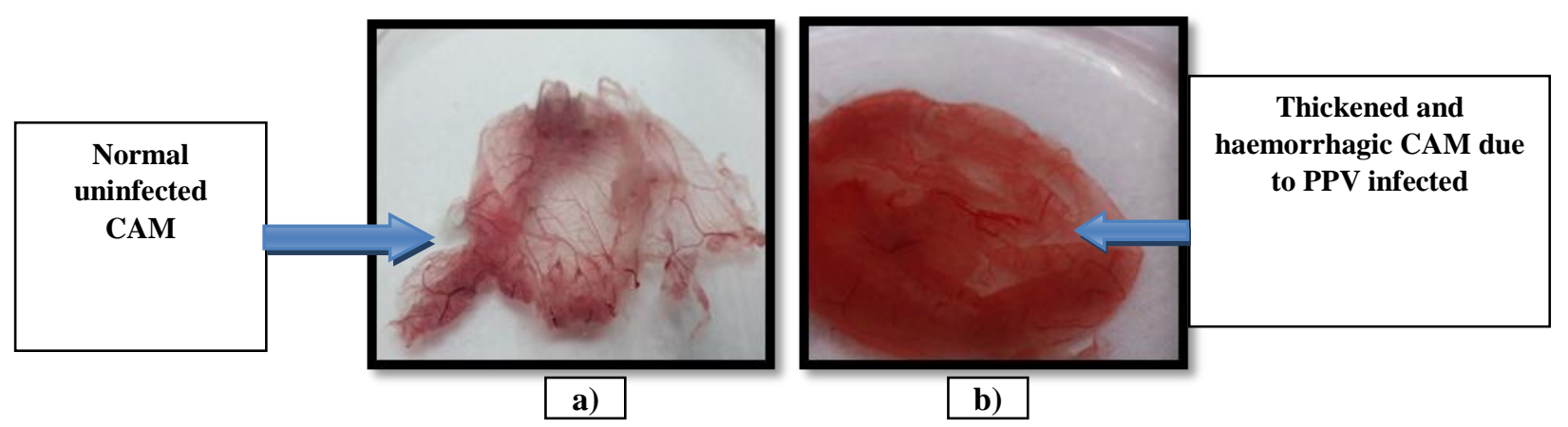

Fig. 4. a) Normal uninfected CAM; b) Pigeon pox infected thickened and haemorrhagic Chicken CAM

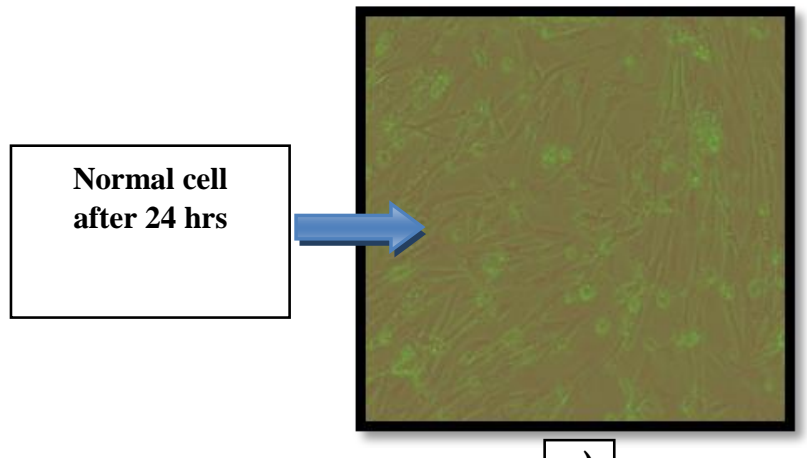

a)

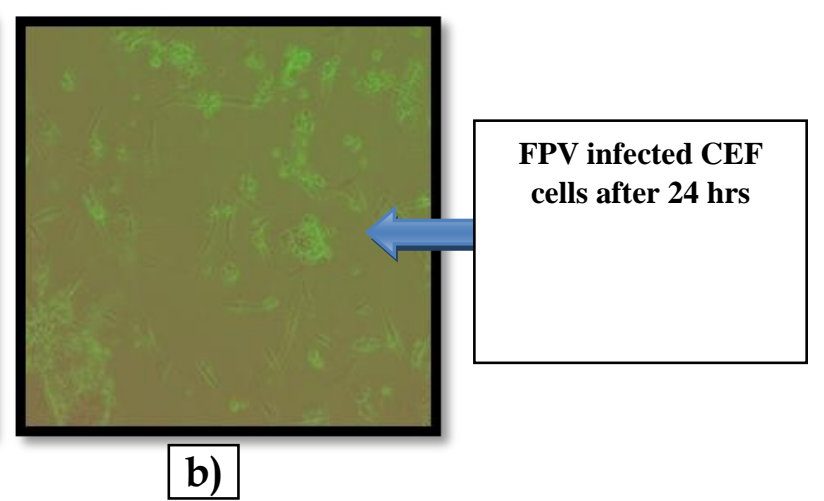

Fig. 5. a) Normal cell and b) FPV infected CEF cell after 24 hours of infection at 10x magnification 


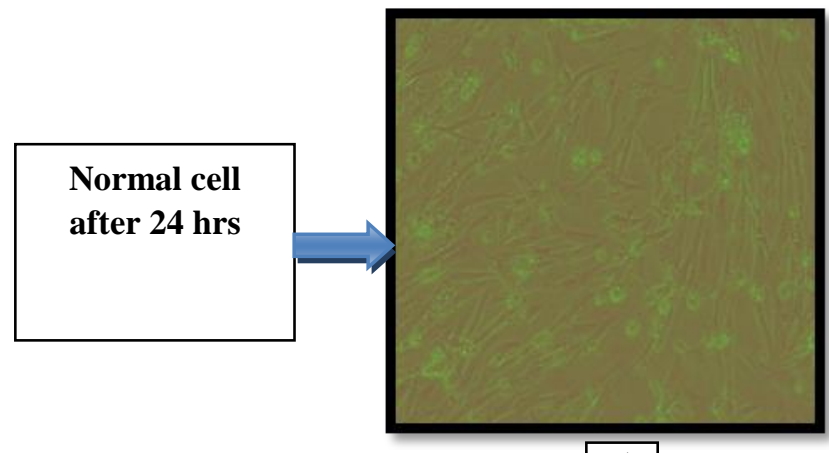

a)
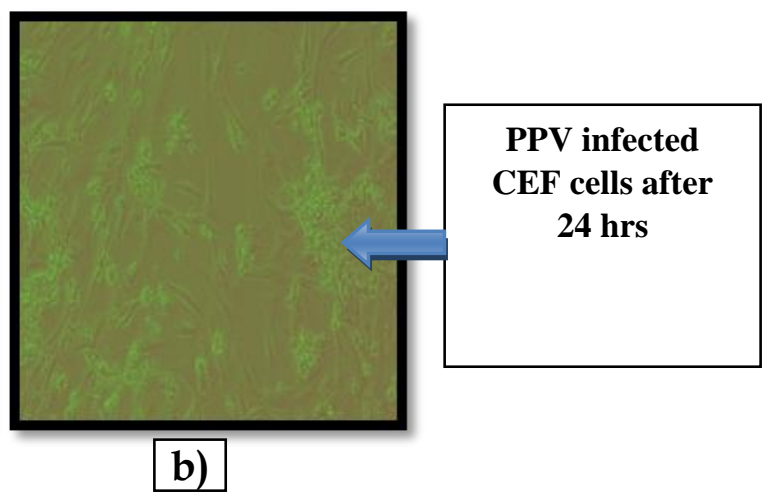

Fig. 6. a) Normal cell and b) PPV infected CEF cell after 24 hours of infection at 10x magnification

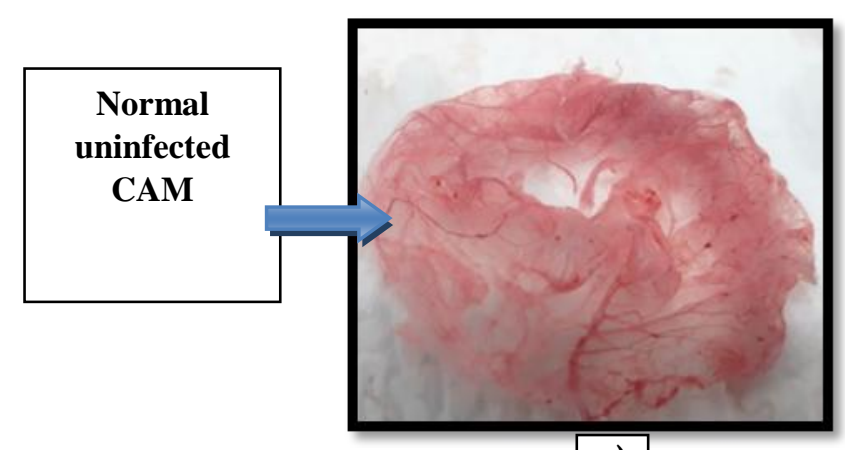

a)

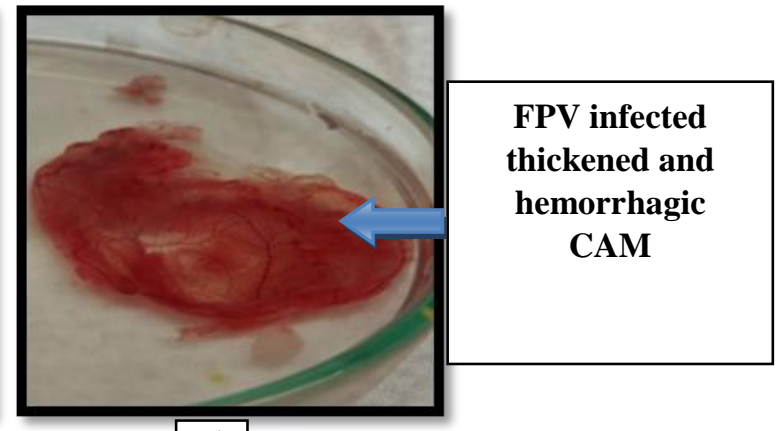

b)

Fig. 7. a) Normal uninfected CAM; b) FPV infected thickened and haemorrhagic Duck CAM

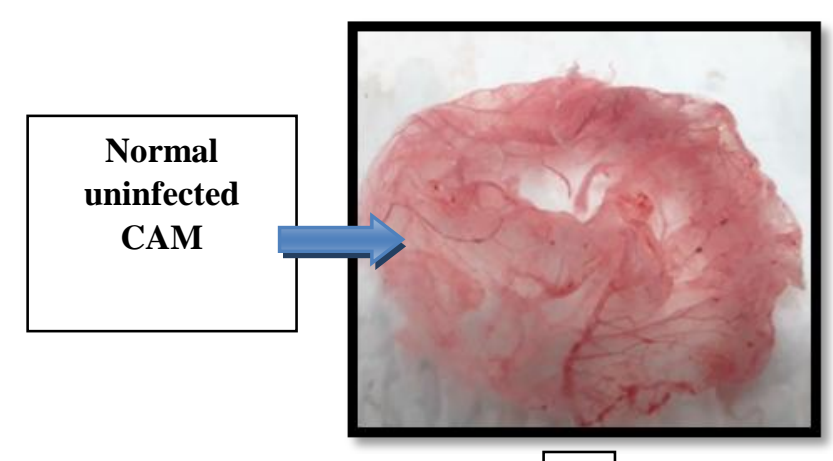

a)

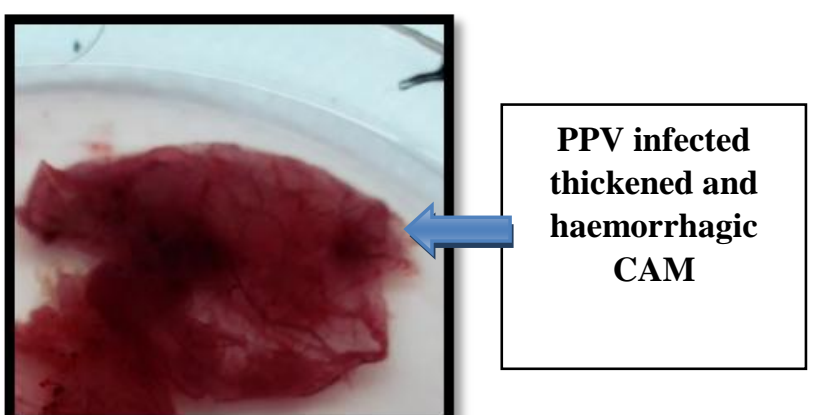

b)

Fig. 8. a) Normal uninfected CAM; b) PPV infected thickened and haemorrhagic Duck CAM

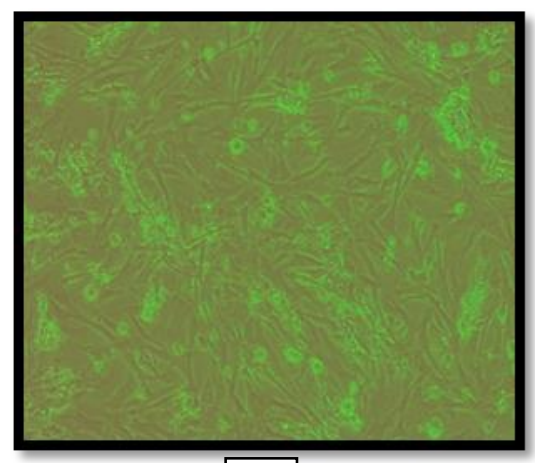

a)

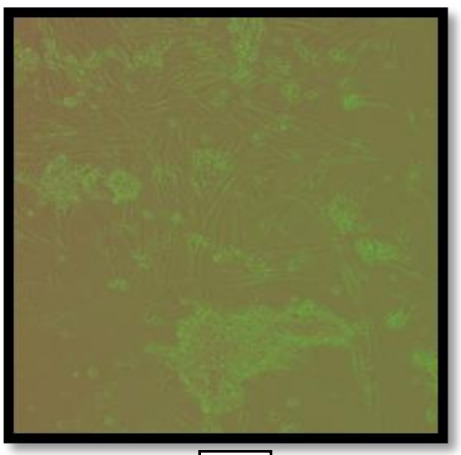

b)

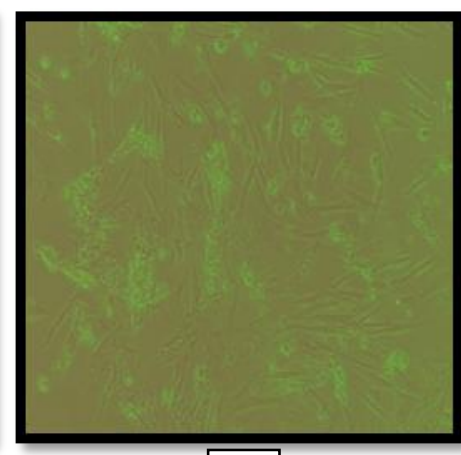

c)

Fig. 9. a) Normal cell ; b) FPV infected DEF cell $5^{\text {th }}$ passage and c) FPV infected DEF cell $6^{\text {th }}$ passage after 24 hours of infection at 10x magnification 


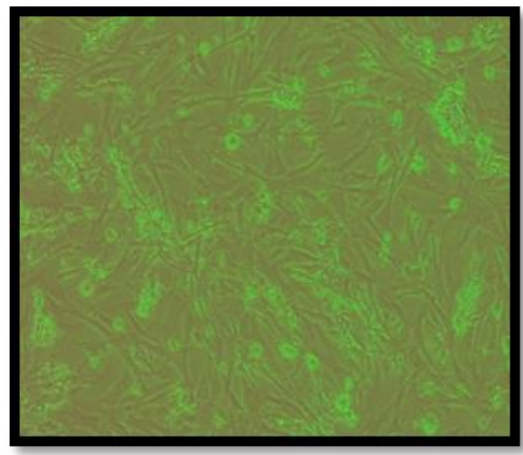

a)

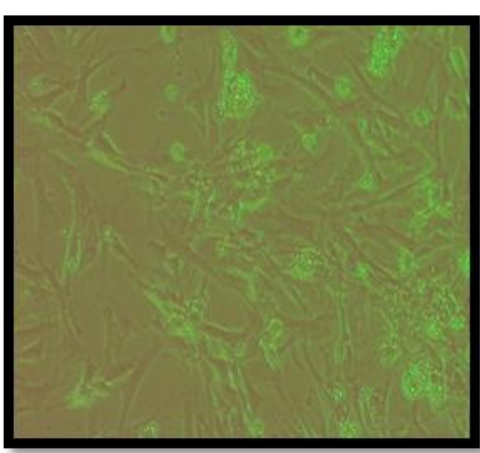

b)

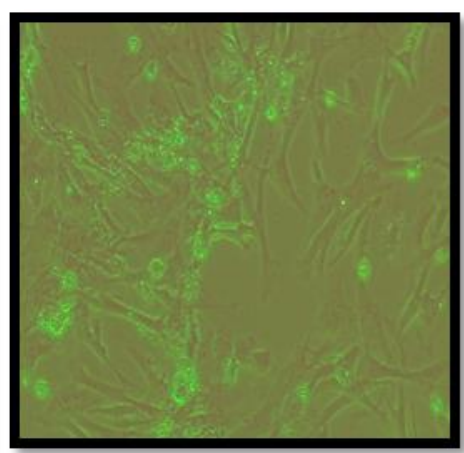

c)

Fig. 10. a) Normal cell ; b) PPV infected DEF cell $5^{\text {th }}$ passage and c) PPV infected DEF cell $6^{\text {th }}$ passage after 24 hours of infection at 10x magnification
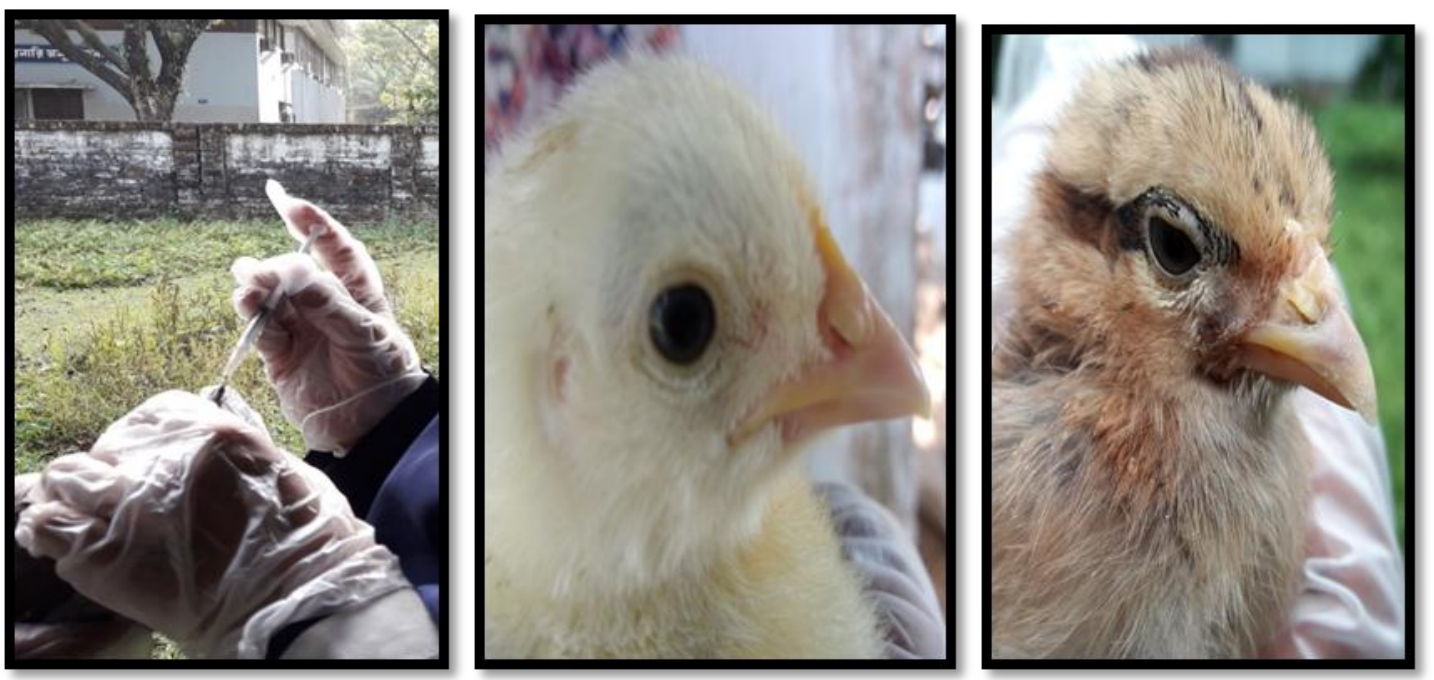

Fig. 11. Infection of fowl of group B with attenuated Fowl pox virus
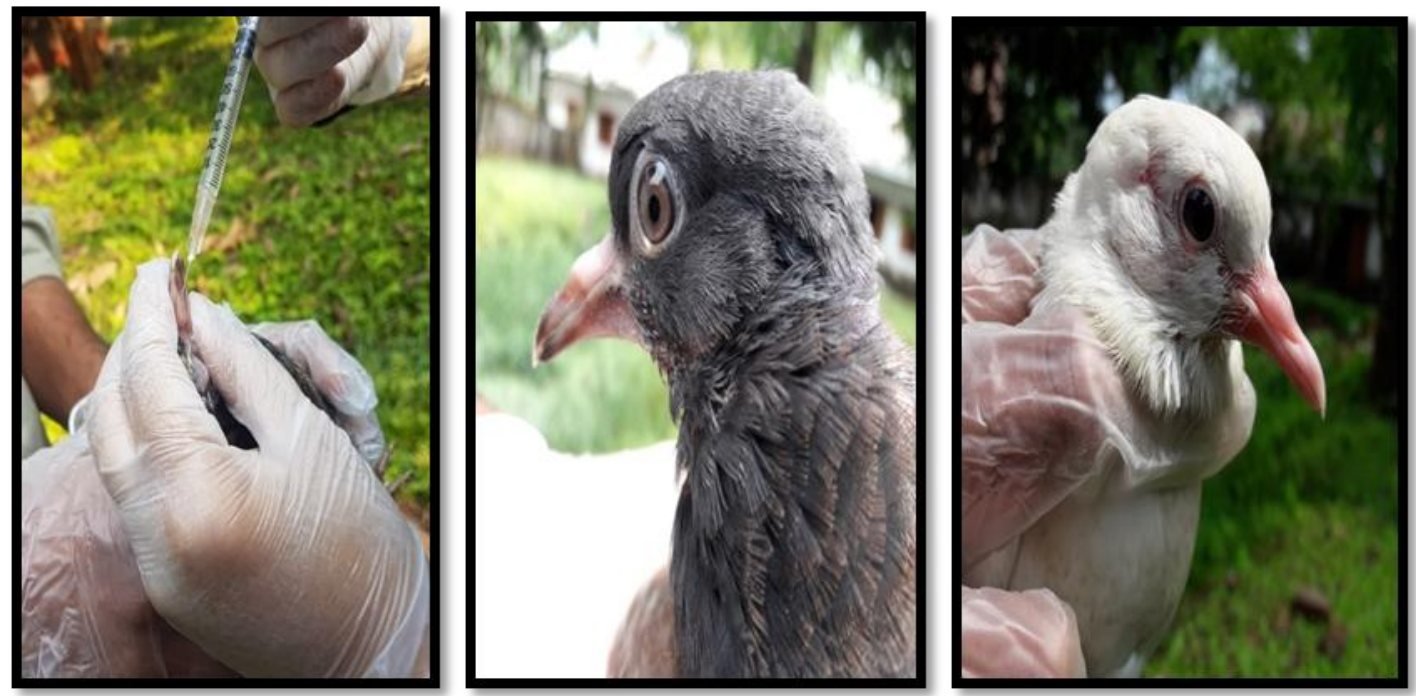

Fig. 12. Infection of pigeon of group B with attenuated Pigeon pox virus 


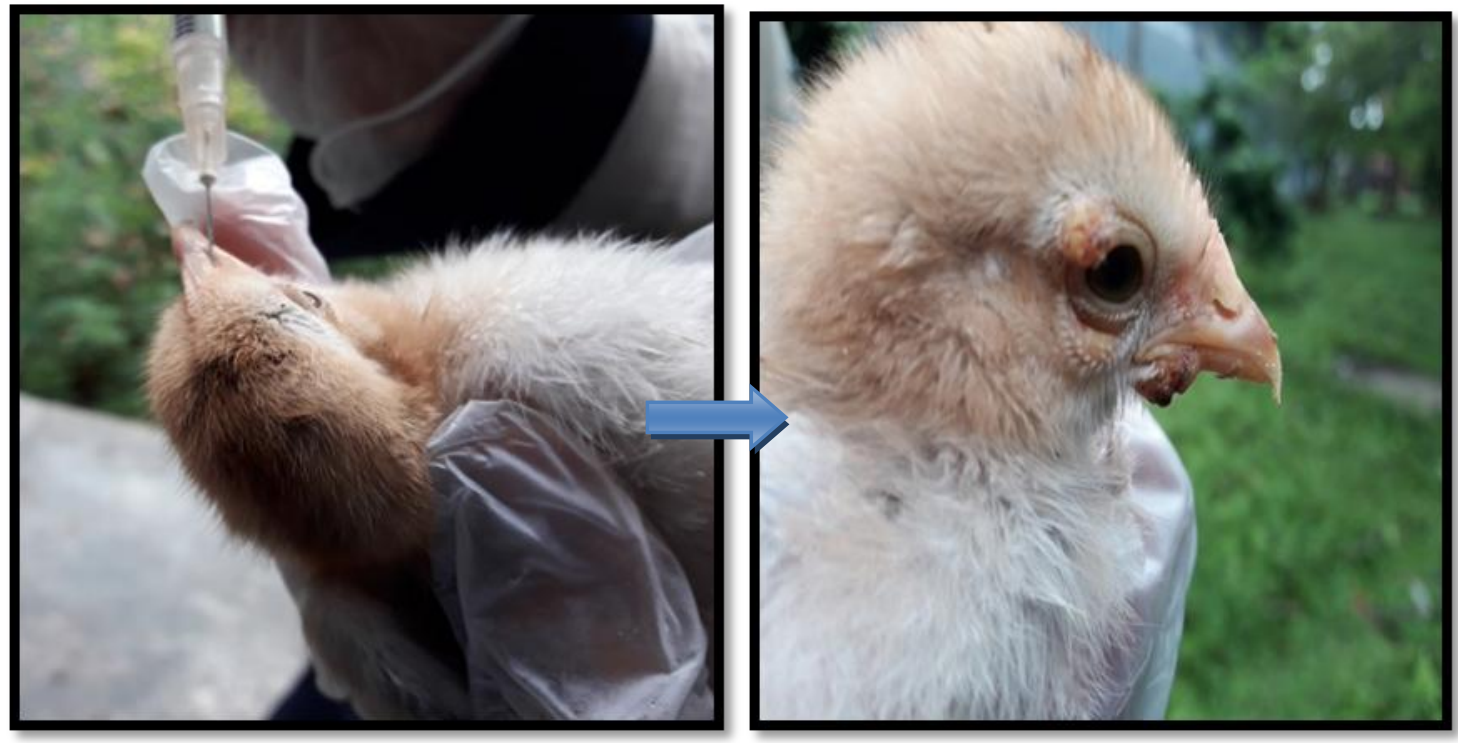

Fig. 13. Infection of fowl of group A by Fowl pox virus
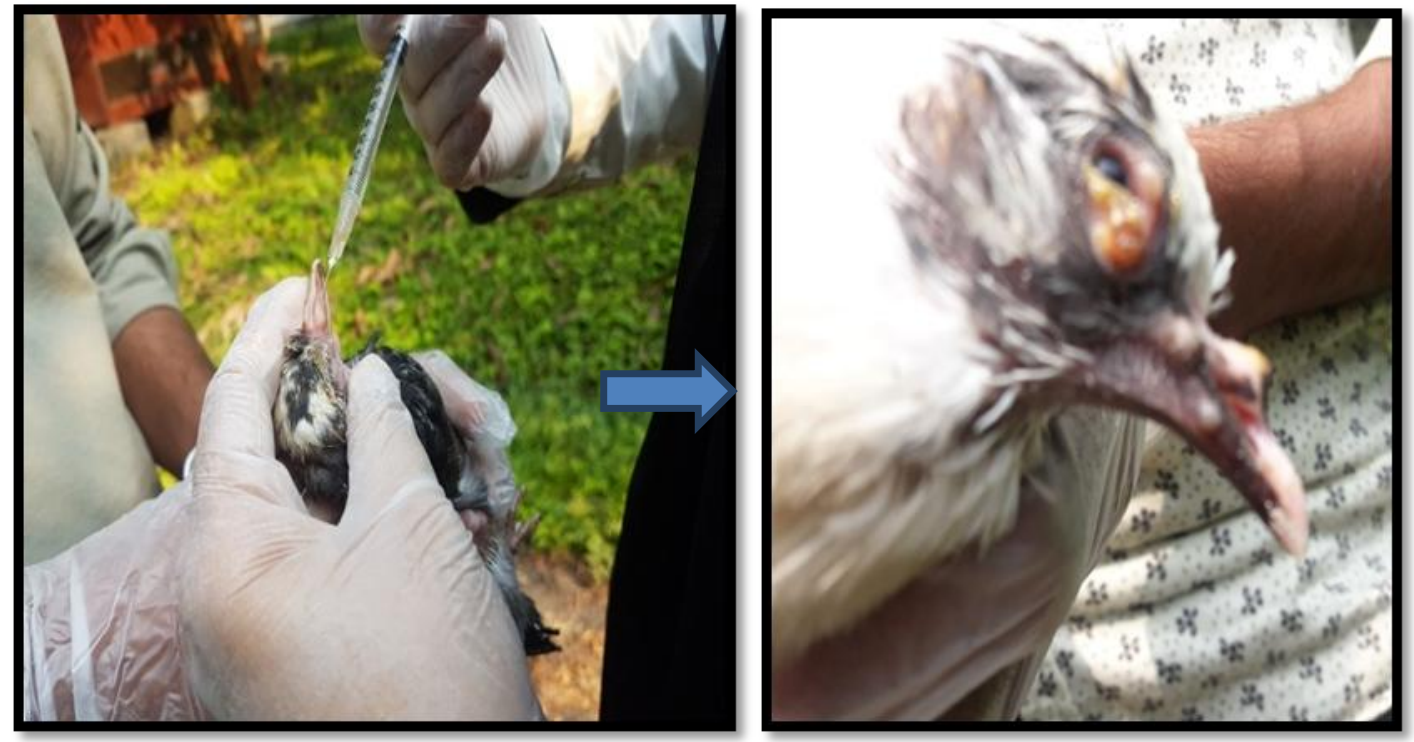

Fig. 14. Infection of pigeon of group A by Pigeon pox virus

Table 3. Effectiveness of Attenuated FPV and PPV in experimental chicks and squabs

\begin{tabular}{llccc}
\hline Inoculated sample & Types of sample & Number of birds & Development of Pox lesion & Attenuation \\
Attenuated vaccine seeds & FPV (CAM) & 2 & 0 & + \\
& FPV (DEF) & 2 & 0 & + \\
& PPV (CAM) & 2 & 0 & + \\
\multirow{2}{*}{ ECE Propagated virus sample } & PPV (DEF) & 2 & 2 & + \\
& FPV (CAM) & 2 & 2 & - \\
\hline
\end{tabular}

Legends, +=Positive, -= Negative

\section{Conclusion}

All the four Fowl pox field samples and seven Pigeon pox field samples were found positive for the presence of FPV and PPV respectively by PCR. Propagation of FPV and PPV was successfully done in chicken embryo both on CAM route and CEF cell culture. Attenuation of FPV and PPV was also done successfully in duck embryo both on CAM route and DEF cell culture for the development of live attenuated vaccine seeds after six serial passages. The attenuation of the developed live attenuated vaccine seeds were checked in experimental birds. These attenuated FPV and PPV can be used as potential vaccine candidate for the eradication of avipox outbreaks in Bangladesh. 


\section{References}

Audarya SD, Riyesh T, KumarN, Chhabra D, Sikrodia R, Sharda R, Barua S, Garg UK 2018: Molecular Diagnosis of a Cutaneous Form of Pox in Pigeons at Mhow in Madhya Pradesh, India. International journal of current microbiology and applied sciences 72319-7706. https://doi.org/10.20546/ijcmas.2018.709.157

Balachandran C, Pazhanivel N, Prabhakar TG, Murugadas V,Prabakar $P$ 2012: Avipox virus infection in rosella parakeet (Platycercus sp.). Journal of Advance Veterinary Research 2 184-187.

Baxendale W 1971: Studies of three avian pox viruses and development of an improved fowl pox vaccine. Veterinary Record88 5-12. http://dx.doi.org/10.1136/vr.88.1.5

Elias A, Chanie M, Mengesha D 2014: A systematic review of serological andclinicopathological features and associated risk factors of avian pox. British Journal of Poultry Sciences3 78-87.DOI: 10.5829/idosi.bjps.2014.3.3.8553

Gelenczei, Emil F, and Lasher HM 1969: Avian pox virus vaccine and process of preparing same. United States Patent No. $3,429,965$.

Hy-Line 2016: Fowl pox in layers. Hy-Line International.www.hyline.com

Islam MR, Khan MS, Islam MA, Kayesh ME, Karim MR, Gani MO, Kabir A 2008: Comparative efficacy of imported fowl pox virus vaccine with locally produced one in backyard chicks. Bangladesh Journal of Veterinary Medicine 6 23-26. https://doi.org/10.3329/bjvm.v6i1.1334

Lee LH, Lee KH 1997: Application of the polymerase chain reaction for the diagnosis of fowl poxvirus infection. Journal Virological Methods 63 113-119. https://doi.org/10.1016/S0166-0934(96)02119-2

Kabir ML, Haque ME, Chakraborty S , Mustafa K , Kamal MM , Khasruzzaman AKM, Khan SR, Islam MA 2015: Isolation and molecular detection of fowl pox and pigeon pox viruses from recent outbreak in Bangladesh. Indian Journal of Life Science. 5: 1-7.

Khan FF 2014:.Studies on field strain of pigeon pox virus and its comparison with field and vaccine strains of fowl pox virus(Doctoral dissertation, Submitted to Chhattisgarh KamdhenuVishwavidyalaya, Durg). http://krishikosh.egranth.ac.in/handle/1/5810018311

Masola SN, Mzula A, Tuntufye HN, KasangaCJ,Wambura PN 2014 Isolation and molecular biological characterization of fowl pox virus from specimen of cutaneous nodular lesions from chickens in several regions of Tanzania. British Microbiology Research Journal. 4: 759-771. https://doi.org/10.9734/BMRJ/2014/8420

Rahman S, Islam MA, Islam MS, Nazir KN, Khan MS 2019: Isolation and molecular detection of Avipoxvirus from field outbreaks in Mymensingh, Bangladesh. Journal of Advanced Veterinary and Animal Research 6 54-59. http://doi.org/10.5455/javar.2019.f314

Reed LJ, Muench H 1938: A simple method of estimating fifty per cent endpoints. American Journal of Epidemiology. 27: 493-497. https://doi.org/10.1093/oxfordjournals.aje.a118408

Roy B, Joardar SN, Samanta I, Das PK, Halder A, Nandi S 2013. Molecular characterization of fowl pox virus isolates from backyard poultry. Advances in Animal and Veterinary Sciences. 1: 54-58.

Tripathy DN, Cunningham CH 1984: Avian pox. In: MS Hofstad, HJ Barnes,BWCalnek, WM Reid, and HW Yoder Jr (Editors), Diseases of Poultry, $8^{\text {th }}$ edition, Iowa State University Press, Ames, Iowa.542-534. https://doi.org/10.1093/oxfordjournals.aje.a118408

Siddique AB, Hossain FM, Zinnah MA 2011: Determination of host specificity of pigeon pox and fowl pox viruses isolated from a field outbreak. Bulgarian Journal of Veterinary Medicine 14 209-214.

Tripathy DN, Reed WM 2003: Pox. In: YM Saif, HJ Barnes, AM Fadly, JR Glisson, LR McDougald and DE Swayne (Editors), Diseases of Poultry (CD version). 11th edition, Iowa State Press Ames. 253-269.

WeliSC,Tryland M 2011: Avipoxviruses: infection biology and their use as vaccine vectors. Virology Journal 8: 49 https://doi.org/10.1186/1743-422X-8-49

Yadav S, Dash BB, Kataria JM, Dhama K, Gupta SK, Rahul S 2007:Pathogenicity study of different avipoxviruses in embryonated chicken eggs and cell cultures. Indian Journal of Veterinary pathology 31: 17-20. 